\title{
Preparation and Characterization of PVC/PMMA Blend Polymer Electrolytes Complexed with $\mathrm{LiN}\left(\mathrm{C}_{2} \mathrm{~F}_{5} \mathrm{SO}_{2}\right)_{2}$
}

\author{
R. Nimma Elizabeth \\ Lady Doak College, India \\ S. Kalyanasundaram, A.Gopalan \\ Alagappa University, India. \\ Y. Saito, A. Manuel Stephan \\ Osaka National Research Institute, Japan
}

\begin{abstract}
Thin films of polymer blend electrolytes comprising Poly(vinyl chloride) (PVC) and Poly(methyl methacrylate)(PMMA) and plasticized with a combination of ethylene carbonate (EC) and propylene carbonate (PC) for different lithium imide salt, $\mathrm{LiN}\left(\mathrm{C}_{2} \mathrm{~F}_{5} \mathrm{SO}_{3}\right)_{2}$, concentrations were prepared using the solution casting technique. The films were subjected to a. c. impedance measurements as a function of temperature ranging from $-30{ }^{\circ} \mathrm{C}$ to $70{ }^{\circ} \mathrm{C}$. The variation of ionic conductivity as a function of temperature and PVC content in the blend was analysed. The role of PMMA in the phenomena occurring at the interface between the plasticized polymer electrolyte and lithium electrode was also studied. The cast films were also subjected to TG/DTA and FT-IR studies which are discussed.
\end{abstract}

Keywords: Polymer electrolyte, plasticizer, Arrhenius plot, lithium-polymer interface.

\section{Introduction}

The development of solid polymer electrolytes with high ionic conductivity at ambient and sub-ambient temperatures has been made extensively due to its potential applications in electrochemical devices, such as high energy-density batteries, electrochromic devices and chemical sensors ${ }^{[1,2]}$. Poly (ethylene oxide) (PEO) based electrolyte is the first and extensively studied system. But its practical applications at ambient temperature is excluded due to the high melting point of the $\mathrm{PEO}$ crystalline phase and co-ordination of $\mathrm{Li}^{+}$ion with oxygen atoms in the PEO amorphous phase, these all - solid state polymer electrolytes have low ionic conductivities $10^{-4}$ to $10^{-5} \mathrm{Scm}^{-1}$, at room temperature ${ }^{[3]}$. Although, poly (acrylonitrile)(PAN) based electrolytes have appealing properties like, high ionic conductivity $\left(10^{-3} \mathrm{Scm}^{-1} \text { at } 25^{\circ} \mathrm{C}\right)^{[4,5]}$ electrochemical stability $4.5 \mathrm{v}$, lithium transference number around 0.6 , their poor compatibility with lithium metal anode remains a problem area ${ }^{[6,7]}$. Iijima et.al., ${ }^{[8]}$ have explored the possibility of using PMMA gel as electrolytes. The electrochemical studies on PMMA with different lithium salts and PMMA, PAN blend based electrolytes have been reported, recently ${ }^{[9-11]}$. In spite of better conductivity and compatibility of PMMA electrolytes with lithium electrodes, their practical application is offset because of poor mechanical strength. Some researchers ${ }^{[12,13]}$ have reported the possibility of using PVC as an electrolyte in lithium batteries.

In the recent past, the importance of using PVC/PMMA blend polymer electrolytes was emphasized by us ${ }^{[14-18]}$ and other researchers ${ }^{[19]}$ in which poly (vinyl chloride) is present as a phase separated, mechanically rigid network that provides the desired mechanical strength to the polymer electrolyte films. In this continuation, so far to our knowledge, not much attention has been paid on the thermal stability and compatibility studies on PVC/PMMA blend polymer electrolytes. The most important finding concluded from the present study is the effect of PMMA on the interfacial resistance, " $\mathrm{R}_{\mathrm{i}}$ " between the lithium electrodes and plasticized PVC-PMMA blend electrolytes. In this paper, the thermal stability and the interaction that exists between the plasticizer and polymer has also been identified using FT-IR studies and are discussed.

\section{Experimental}

PVC, mol. wt $1.5 \times 10^{5}$ and PMMA, mol. wt. of $3.5 \times 10^{5}$ (Aldrich, USA) were used in the present study. The plasticizers ethylene carbonate (EC) and propylene carbonate (PC) (E. Merck, Germany) were used as such without further purification. The lithium salt, $\operatorname{LiN}\left(\mathrm{C}_{2} \mathrm{~F}_{5} \mathrm{SO}_{3}\right)_{2}$ was dried at $70{ }^{\circ} \mathrm{C}$ and kept under vacuum for $48 \mathrm{~h}$ before use. Among the lithium salts commonly used $\mathrm{LiN}\left(\mathrm{C}_{2} \mathrm{~F}_{5} \mathrm{SO}_{2}\right)_{2}$ may be promising for industrial applications due to its larger anion size and higher polarizability. Also, it is more effective in terms of the cation transport properties ${ }^{[20]}$. All the electrolytes were prepared by dissolving, appropriate amounts of polymer, plasticizer and lithium salt in anhydrous tetrahydrofuran (THF) as indicated in Table I. 
Table 1. Composition of polymer, plasticizers and lithium salt.

\begin{tabular}{|c|c|c|c|c|c|c|}
\hline \multirow[t]{2}{*}{$\begin{array}{c}\text { Sample } \\
{[\mathrm{g}]}\end{array}$} & \multicolumn{2}{|c|}{$\begin{array}{c}\text { wt. of polymer } \\
{[\mathrm{g}]}\end{array}$} & \multicolumn{2}{|c|}{$\begin{array}{c}\text { wt. of } \\
\text { plasticizer } \\
\text { [g] }\end{array}$} & \multicolumn{2}{|c|}{$\begin{array}{c}\text { wt. of } \mathbf{L i} \text { salt } \\
\text { plasticizer } \\
\text { content } \\
{[\mathrm{g}]}\end{array}$} \\
\hline & PVC & PMMA & EC & PC & LiN( & $\left.{ }_{5} \mathrm{SO}_{2}\right)_{2}$ \\
\hline $\mathrm{S}_{1}$ & 14.75 & 44.25 & 27.5 & 12.5 & 1 & $40 \%$ \\
\hline $\mathrm{S}_{2}$ & 12 & 36 & 30 & 20 & 2 & $50 \%$ \\
\hline $\mathrm{S}_{3}$ & 10.5 & 31.5 & 32 & 23 & 3 & $55 \%$ \\
\hline $\mathrm{S}_{4}$ & 9 & 27 & 35 & 25 & 4 & $60 \%$ \\
\hline $\mathrm{S}_{5}$ & 6.25 & 18.75 & 40 & 30 & 5 & $70 \%$ \\
\hline $\mathrm{S}_{6}$ & 0 & 35 & 35 & 25 & 5 & $60 \%$ \\
\hline $\mathrm{S}_{7}$ & 26.5 & 8.5 & 35 & 25 & 5 & $60 \%$ \\
\hline $\mathrm{S}_{8}$ & 17.5 & 17.5 & 35 & 25 & 5 & $60 \%$ \\
\hline $\mathrm{S}_{9}$ & 35 & 0 & 35 & 25 & 5 & $60 \%$ \\
\hline
\end{tabular}

The solutions were cast as films using doctor blade method as reported elsewhere ${ }^{[14-16]}$ and allowed to evaporate at ambient temperature. After evaporation of THF, the films were further dried in a temperature-controlled oven over $50^{\circ} \mathrm{C}$ for $8 \mathrm{~h}$ to remove any traces of THF. All samples were prepared in a glove box under argon atmosphere and stored in a desiccators inside the glove box to minimize water contamination.

Conductivity measurements were performed by sandwiching the polymer electrolyte between two stainless steel electrodes of diameter $1 \mathrm{~cm}$ using an EIS electrochemical analyzer (EG\&G Princeton Instruments Model 6310A USA) over a frequency of $10 \mathrm{~Hz}$ to $100 \mathrm{KHz}$ at nine different temperatures viz. $-30,-15,0,15,30,40,50,60$, and $70{ }^{\circ} \mathrm{C}$. The cast films were also subjected to thermogravimetry -differential thermal analysis (TG/DTA) (Rigaku TG8101D, Japan) in argon atmosphere with the heating rate of $10^{\circ} \mathrm{C} / \mathrm{min}$. The infrared spectra were recorded (Perkin -Elmer STA 5000, USA) from $400 \mathrm{~cm}^{-1}$ to $4000 \mathrm{~cm}^{-1}$ with a resolution of $1 \mathrm{~cm}^{-1}$ at room temperature. The samples were prepared as thin films and mounted between potassium bromide windows.

\section{Results and Discussion}

\section{Conductivity studies}

Electrochemical impedance spectroscopy is a relatively new and powerful method to characterize many of the electrical properties of materials and their interfaces with the electronically conducting electrodes. It may be used to investigate the dynamics of bound or mobile charge in the bulk or interfacial regions of any kind of solid or liquid material: ionic, semiconducting, mixed electronic - ionic and even insulators (dielectrics). The ionic conductivities of PVC/

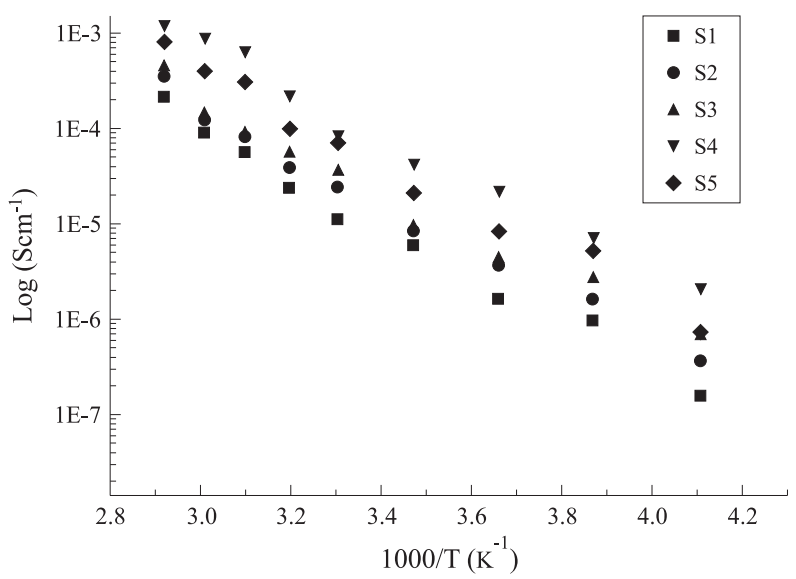

Figure 1.Temperature dependence of ionic conductivity for the films with different salt and plasticizer content ( salt: $\left.\mathrm{LiN}\left(\mathrm{C}_{2} \mathrm{~F}_{5} \mathrm{SO}_{2}\right)_{2}\right)$

PMMA blend electrolytes were measured with an intention of finding out the part played by PMMA in the blend. Hence, the ionic conductivities of the PVC/PMMA blend electrolytes were measured by varying the content of the blend in the proportionate ratio as displayed in Table 1.

The variation of ionic conductivity has been analyzed for various lithium salts by a) varying the PVC/PMMA blend ratio, keeping the plasticizer content fixed and $b$ ) varying the plasticizer content, (EC/PC) keeping the PVC/PMMA blend ratio constant .

Figure 1 shows the variation of ionic conductivity as a function of plasticizer content with fixed PVC (25\%) / PMMA (75\%) blend ratio containing $\operatorname{LiN}\left(\mathrm{C}_{2} \mathrm{~F}_{5} \mathrm{SO}_{2}\right)_{2}$ as the lithium salt for the samples $\mathrm{S}_{1}, \mathrm{~S}_{2}, \mathrm{~S}_{3}, \mathrm{~S}_{4}$ and $\mathrm{S}_{5}$ of in Table 1. It is clear from figure, that the ionic conductivity increases with the increase of plasticizer content and salt concentration.

The ionic conductivity increases with the increase of salt concentration, to a level, i.e., up to $60 \%$ of the plasticizer content, and then decreases $\left(\mathrm{S}_{5}\right)$ for further increase in plasticizer and salt concentration. The same trend was observed for all the temperatures studied from -30 to $70^{\circ} \mathrm{C}$.

Generally contribution from the plasticizer towards the enhancement of conductivity is two fold: a higher percentage of plasticizer would (i) open up the narrow rivulets of plasticizer - rich phase for greater ionic transport, and (ii) provide a large free volume of relatively superior conducting phase $^{[19]}$.

The maximum on the conductivity- salt concentration curve may be explained as follows. Up to the concentration level, (60\% of plasticizer content) corresponding to the conductivity plateau, more and more number of ions are made available for electrolytic conduction. At higher concentration in low dielectric media, essentially two types of ion pairs are present $^{[17]}$.

These may be represented by the equilibria for the membranes containing $\mathrm{LiN}\left(\mathrm{C}_{2} \mathrm{~F}_{5} \mathrm{SO}_{2}\right)_{2}{ }^{-}$ions as follows

$$
\begin{aligned}
& \mathrm{Li}^{+} \mathrm{S}_{\mathrm{n}}+\mathrm{N}\left(\mathrm{C}_{2} \mathrm{~F}_{5} \mathrm{SO}_{2}\right)_{2}{ }^{-}=\left(\mathrm{Li}^{+}\right) \mathrm{S}_{\mathrm{n}} \mathrm{N}\left(\mathrm{C}_{2} \mathrm{~F}_{5} \mathrm{SO}_{2}\right)_{2}^{-} \\
& \mathrm{Li}^{+} \mathrm{S}_{\mathrm{n}}+\mathrm{N}\left(\mathrm{C}_{2} \mathrm{~F}_{5} \mathrm{SO}_{2}\right)_{2}^{-}=\left(\mathrm{Li}^{+} \mathrm{N}\left(\mathrm{C}_{2} \mathrm{~F}_{5} \mathrm{SO}_{2}\right)_{2}^{-}\right) \mathrm{S}_{\mathrm{n}-\mathrm{m}}+\mathrm{S}_{\mathrm{m}} .
\end{aligned}
$$




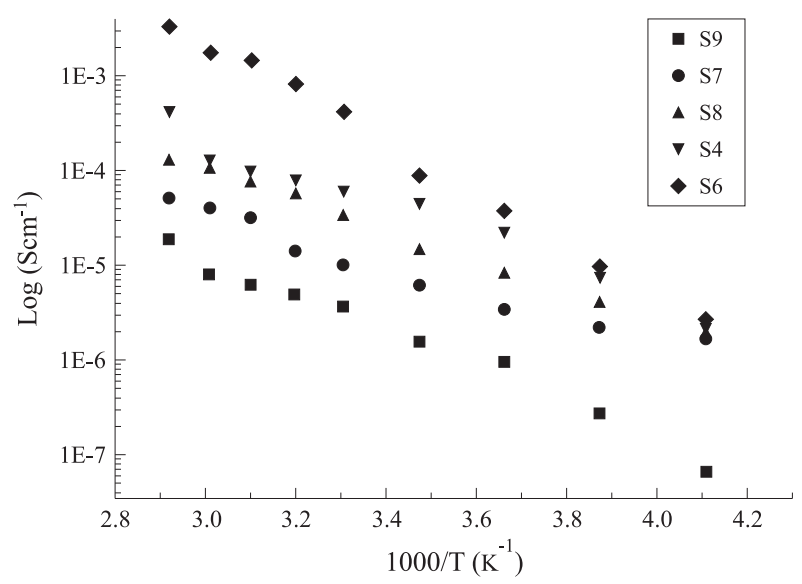

Figure 2. Temperature dependence of ionic conductivity for the films with different PVC/PMMA blend ratio (plasticizer content $60 \%$ )

Where S represents the solvating species. Re-dissociation of such ion pairs can occur due to long range coulombic forces giving rise to free ions, which contribute to conductance. At higher concentrations, short range ion-solvent interactions take over and therefore, even though the number of ions dissolved in the electrolyte medium is higher, the effective number of charged species available for charge transport gets reduced ${ }^{[17]}$.

Figure 2 represents the dependency of ionic conductivity of the films containing $\mathrm{LiN}\left(\mathrm{C}_{2} \mathrm{~F}_{5} \mathrm{SO}_{2}\right)_{2}$ for different $\mathrm{PVC} /$ PMMA blend ratio at a fixed plasticizer content (60\%wt.,). It is seen from the figure that the conductivities range from 5.2 $\mathrm{X} 10^{-8}$ to $5.0 \times 10^{-6} \mathrm{Scm}^{-1}$ at $-30{ }^{\circ} \mathrm{C}$ for different blend ratios. The conductivity is found to increase with the increase of PMMA content in the blend. For the sample, the film, which does not contain PVC (in other words $100 \%$ PMMA) $\left(\mathrm{S}_{6}\right)$ exhibited highest conductivity at all temperatures studied. However, the mechanical property of this film was poor i.e. the film was not free standing but forms a gel at room temperature. On the other hand, the sample which does not contain PMMA (i.e., $100 \%$ PVC) $\left(\mathrm{S}_{9}\right)$, the conductivity was found to be $3.0 \times 10^{-8} \mathrm{Scm}^{-1}$ at $-30{ }^{\circ} \mathrm{C}$ which is two orders of magnitude lower than that of the sample containing $100 \%$ PMMA. Also, this sample is free standing with good mechanical strength. Interestingly, the film with intermediate blend ratio of PMMA (75): PVC (25) and PMMA (50): PVC (50) $\left(\mathrm{S}_{8}\right)$ showed good mechanical property. However, their conductivities were a little lower than that of the film with $100 \%$ PMMA.

It is evident that the PVC rich phase acts effectively as a mechanical support for the electrolyte film and the PMMA phase facilitates for ionic conduction. From the results, it is believed that in these electrolyte films the PVC rich phase acts as a mechanical support and the plasticizer rich phase (EC-PC) interconnected with each other acts as a tunnel for ionic transport. Since the PVC-rich phase is like a solid medium, it hinders the ionic migration. This concept has already well been substantiated by Rhoo et al., ${ }^{[19]}$ and Stephan et al., ${ }^{[15]}$ using SEM analysis on PVC/PMMA blend electrolytes. Due to such a blocking nature of the PVC-rich phase, the transport of ions must occur in a indirect motion along a convoluted path restricted to the plasticzer- rich phase, which would be responsible for the low conductivity with high PVC content.

On the other hand, films with no PVC, only a homogenous conducting medium exists in the film, which results in a direct drift of the ion, and consequently this is the reason for high ionic conductivity $\left(2.0 \times 10^{-6} \mathrm{~S} \mathrm{~cm}^{-1}\right)$.

Obviously, it is observed from the figure, that the ionic conductivity increases with the increase in temperature. It is also evident from the figures, that ionic conduction obeys the VTF relation, $\Lambda=\mathrm{AT}^{-1 / 2} \exp \left(-\mathrm{B} /\left(\mathrm{T}-\mathrm{T}_{0}\right)\right)$ where $\Lambda$ is the molal conductance, $\mathrm{A}$ and $\mathrm{B}$ are constants and $\mathrm{T}_{\mathrm{o}}$ is the temperature at which the conductance tends to zero, and this equation describes the transport properties in a viscous matrix ${ }^{[13,27]}$. It supports the idea of ionic conduction taking place through the plasticizer-rich phase $\mathrm{e}^{[15]}$.

\section{Compatibility}

It is widely known, the charge-discharge performance are influenced by the characteristics of an interface between a lithium metal anode and an organic electrolyte. The chargedischarge cycling efficiency has been limited for the use of secondary batteries with lithium metal anode. Many attempts have been reported to increase the cycling efficiency, by using organic, inorganic and gaseous additives to the electrolytes for the rechargeable Li-batteries ${ }^{[23]}$. Mostly the chemical properties of the Li-interface are known to affect the $\mathrm{Li}$ cycling efficiency.

In polymer electrolyte systems, a resistive layer covers the lithium and the resistance of this layer grows with time can reach values over $10 \mathrm{~K} \Omega \mathrm{cm}^{-2[23,24]}$. The structure of this layer is not understood, but it is known, that uncontrolled passivation phenomena affect the cyclability of lithium electrodes and thereby entire lithium battery system. It is also suspected that the nature of this layer depends mainly on the purity and composition of the electrolyte. This solid electrolyte interface (SEI) plays a major role in determining their properties, which include shelf life, safety and lithium deposition-dissolution efficiency and cycle life.

In order to determine the stability of the lithium metal, with the polymer electrolyte interface over time, a detailed impedance analysis of a symmetric cell of the type Li/polymer electrolyte/Li was assembled and tested under open circuit condition at $25^{\circ} \mathrm{C}$. From the ionic conductivity studies, it has been found that the sample with PVC/PMMA blend of ratio $25: 75\left(\mathrm{~S}_{7}\right)$ is found to be optimal from ionic conductivity and mechanical points of view. Hence, for compatibility, TG/DTA and FTIR studies sample $\mathrm{S}_{7}$ was chosen. Figure 3 displays the variation of interfacial resistance " $R_{i}$ " as a function of time for the polymer electrolytes at $25^{\circ} \mathrm{C}$. In fact, the increase of " $\mathrm{R}_{\mathrm{i}}$ " may generally be ascribed due to a resistive layer continuously growing on lithium electrode surface ${ }^{[25,26]}$. It indicates, that the lithium electrode is passivated when in contact with the polymer electrolytes. The increase of " $\mathrm{R}_{\mathrm{i}}$ " is not surprising as some of the electrolyte components like, propylene carbonate is corrosive of lithium 


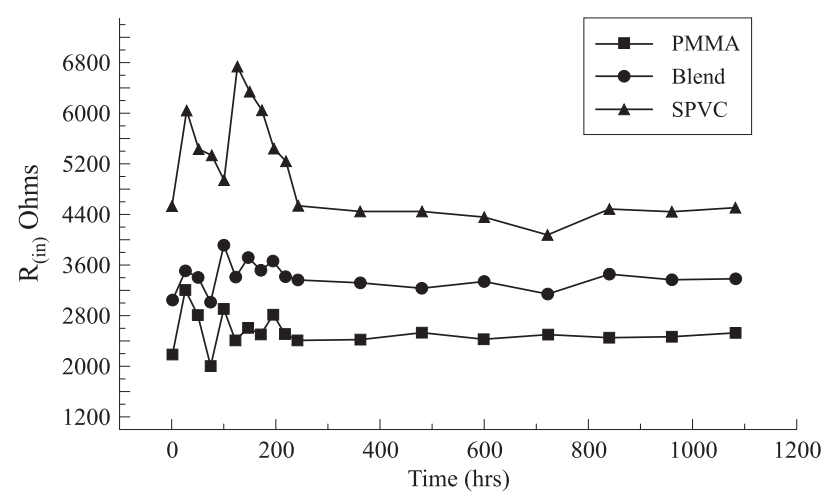

Figure 3. Time evolution of interfacial resistance " $\mathrm{R}_{i}$ " for Li-polymer electrolyte-Li cell at $25^{\circ} \mathrm{C}$ under open circuit conditions. $\mathbf{\square}-\mathrm{S}_{6} \bullet-\mathrm{S}_{4} \Delta-\mathrm{S}_{9}$

metal. It is also evident from the figure, that the growth of resistive layer does not follow a regular way. After, 200 hours the resistance values remain unchanged. This may be attributed, by assuming the morphology of the passivation films changes with time to finally acquire a non-compact, possibly porous structure ${ }^{[9]}$. It is also seen from the figure 3 the values of " $\mathrm{R}_{\mathrm{i}}$ " are higher for the films with $100 \%$ PVC than the films with $100 \%$ PMMA. More interestingly, in the case of PVC/PMMA blend polymer electrolytes the value of " $R_{i}$ " lies between these two. ie, the value of " $R_{i}$ " has considerably been reduced with the addition of PMMA.

As it has been discussed earlier ${ }^{[27]}$, the formation of passive layer normally takes place in two steps. In the first step, the "primary film" is formed with initial resistance $\mathrm{R}_{\mathrm{i}}$ and is most probably due to the addition of polymer end groups and metallic lithium. The second step involves the chemical properties of electrolytes and therefore the secondary film is normally called as solid electrolyte interface (SEI ${ }^{[23]}$ and properties of this film depend on electrolyte composition, salt and the transference number of the ions ${ }^{[24-26]}$. The possibility that can explain the reduction of the interfacial resistance " $R_{i}$ " for the films containing PMMA is attributed due to the reaction of lithium cations with the ester groups of PMMA and the formation of a protective layer close to the electrode- electrolyte interface ${ }^{[27]}$. The effect of this layer may protect the Li from the impurities present in the electrolyte ${ }^{[27]}$. More attention should be paid to suppress the formation of passivation films. The propylene carbonate may decompose in the presence of lithium metal and form propylene and $\mathrm{Li}_{2} \mathrm{CO}_{3}{ }^{[28]}$. Polypropylene oxide and carbon dioxide may be formed as a result of polymerization of propylene carbonate ${ }^{[29]}$. The polymer macromolecules may be cross-linked through free radical couplings in the presence of lithium metal ${ }^{[29]}$. Therefore, the passivation film may contain all the products of the unexpected reactions of lithium electrodes with PC and the carbonyl groups on the polymer chains.

\section{Electrochemical Stability}

An electrochemical window greater than $4.5 \mathrm{~V}$ is an important parameter for a polymer electrolyte for applications in polymer based lithium batteries. The electrochemical stability studies for the PMMA and PVC films have already been reported ${ }^{[9,13]}$. Figure 4 depicts the current-voltage curves

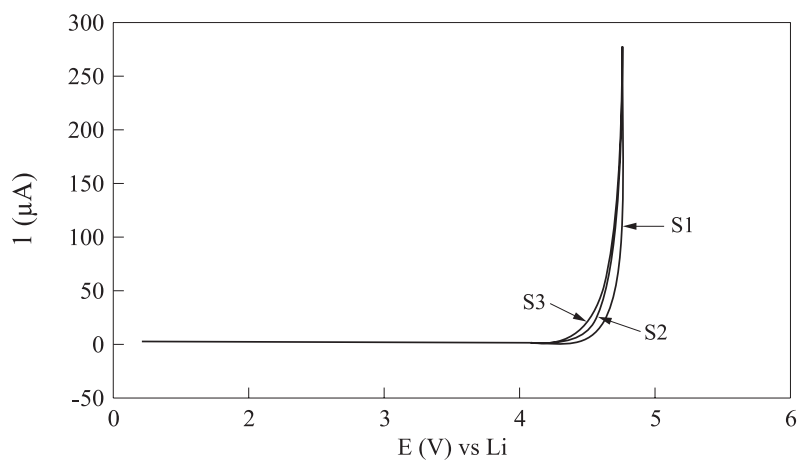

Figure 4. Current - voltage response at $25^{\circ} \mathrm{C}$ of an SS-polymer electrolyte$\mathrm{SS}$ cell. (a) PVC-EC-PC-LiN $\left(\mathrm{C}_{2} \mathrm{~F}_{5} \mathrm{SO}_{2}\right)_{2}$ (b) PVC-PMMA-EC-PC$\mathrm{LiN}\left(\mathrm{C}_{2} \mathrm{~F}_{5} \mathrm{SO}_{2}\right)_{2}$ (c) PMMA-EC-PC- LiN $\left(\mathrm{C}_{2} \mathrm{~F}_{5} \mathrm{SO}_{2}\right)_{2}\left(\right.$ Scan rate $\left.5 \mathrm{mVs}^{-1}\right)$

obtained by sweeping a stainless steel (SS) electrode and polymer electrolytes at $25^{\circ} \mathrm{C}$. The anodic decomposition limit of the electrolyte can be considered as the voltage at which the current flows through the cell ${ }^{[9,13,30]}$. It is clear, from the figure that electrolytes with $\mathrm{LiN}\left(\mathrm{C}_{2} \mathrm{~F}_{5} \mathrm{SO}_{2}\right)_{2}$ as salt have an anodic stability above $4.7 \mathrm{~V}$ vs $\mathrm{Li}$ and electrolytes may be compatible with high voltage electrodic couples such as $\mathrm{LiC}_{6}$, $\mathrm{LiMn}_{2} \mathrm{O}_{4}$, etc $^{[9]}$.

\section{Thermal Stability}

\section{TG/DTA analysis}

To ascertain the thermal stability of polymer electrolytes, prepared samples were subjected to TG/DTA analysis. The TG-DTA analysis results for PVC, PMMA, PVC-PMMA and PVC-PMMA-EC-PC are shown in figures 5(a-d). It is seen for the polymer, PVC, no weight loss was observed until $270{ }^{\circ} \mathrm{C}$ followed by a weight loss DTA exothermic peak, which clearly shows that PVC is stable up to $270{ }^{\circ} \mathrm{C}$. Similarly, PMMA is also stable up to $230^{\circ} \mathrm{C}$ (Fig 5b). In the case of PVC-PMMA blend polymer, the decomposition temperature is still lower, $210^{\circ} \mathrm{C}$ (Figure5c). From figure 5(d) when EC and PC are added as plasticizers in the blend the decomposition temperature has further been decreased to $130{ }^{\circ} \mathrm{C}$. This may be attributed due to the addition of plasticizers, which decomposes around $130{ }^{\circ} \mathrm{C}^{[14]}$.

Figure 5(e) shows the TG-DTA curves of the polymer electrolytes with $\mathrm{LiN}\left(\mathrm{C}_{2} \mathrm{~F}_{5} \mathrm{SO}_{3}\right)_{2}$. It is interesting, to note from the TG-DTA analysis for the polymer film, PMMA-EC-PC$\mathrm{LiN}\left(\mathrm{C}_{2} \mathrm{~F}_{5} \mathrm{SO}_{3}\right)_{2}$, an endothermic peak is seen at about $35^{\circ} \mathrm{C}$ with less than $2 \%$ weight loss, which is attributed due to the presence of moisture and impurities mainly due to fluorine $\mathrm{e}^{[31,32]}$. The polymer electrolyte decomposes at about $90{ }^{\circ} \mathrm{C}^{[14,31]}$. Obviously, it is clear from these observations that these films can be operated up to $90^{\circ} \mathrm{C}$ and are preferred in the lithium polymer batteries as its operating temperature is normally in the range of $40-70{ }^{\circ} \mathrm{C}^{[14]}$.

\section{FT-IR Studies}

In order to explore the possible molecular interactions of the plasticizer with the host polymer matrix the FT-IR studies have been made. It should be noted that, these data are 

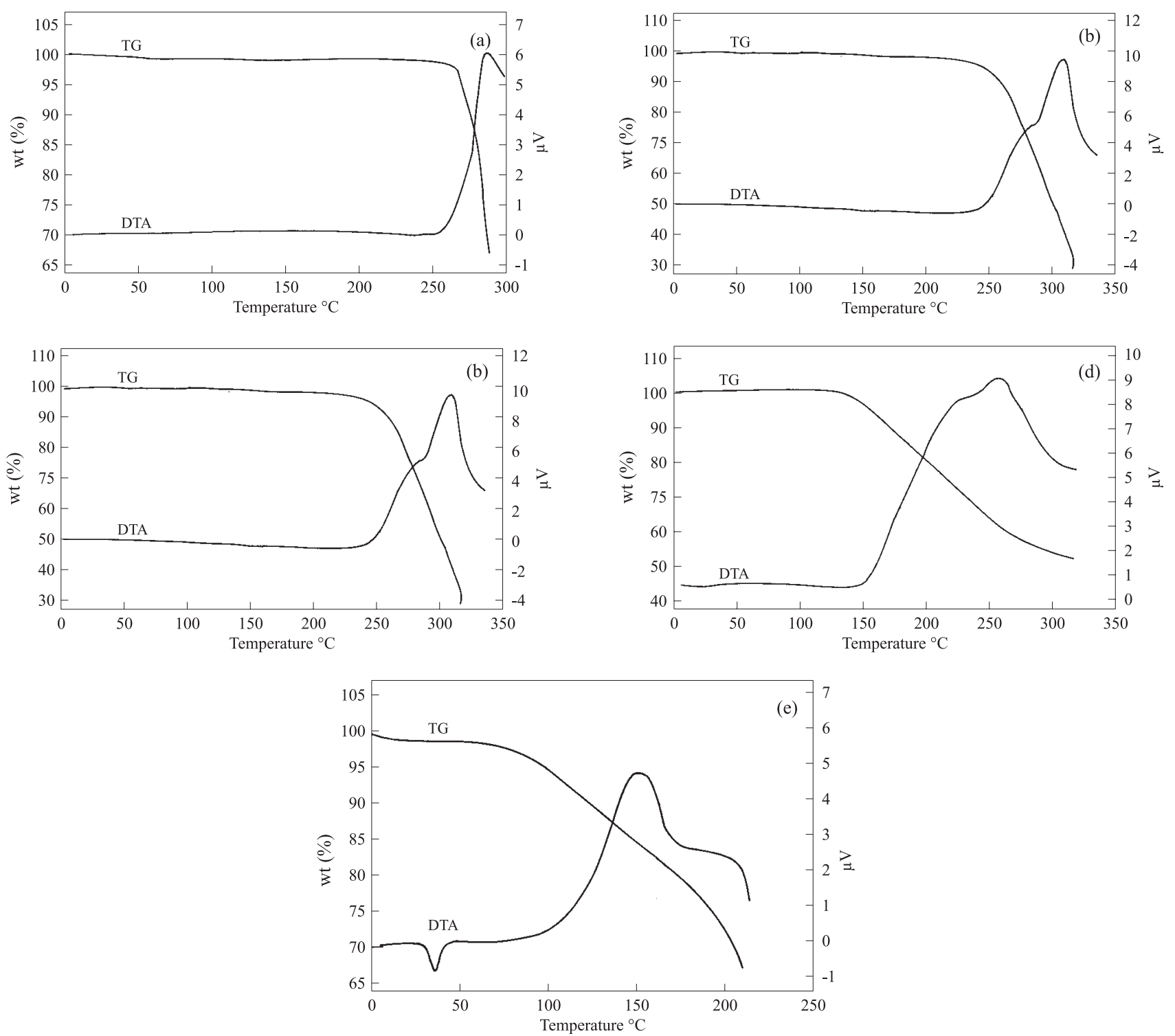

Figure 5. TG-DTA traces of (a) PVC (b) PMMA (c) PVC-PMMA (d) PVC-PMMA-EC-PC (e) PVC-PMMA-EC-PC-LiN $\left(\mathrm{C}_{2} \mathrm{~F}_{5} \mathrm{SO}_{2}\right)_{2}$

analysed only from the angle of symmetric ring deformation region, $\mathrm{C}=\mathrm{O}$ stretching region of $\mathrm{PC}$ and the ring breathing and ring bending regions of $\mathrm{EC}$ when they act as plasticizer containing $\mathrm{LiN}\left(\mathrm{C}_{2} \mathrm{~F}_{5} \mathrm{SO}_{2}\right)_{2}$ as salt.

FT-IR spectra of PMMA, PVC, and PVC-PMMA-EC$\mathrm{PC}$ - $\mathrm{LiN}\left(\mathrm{C}_{2} \mathrm{~F}_{5} \mathrm{SO}_{2}\right)_{2}$ are shown in Figure6(a-c). Figure7 (a-f) displays the symmetric ring deformation region of $\mathrm{PC}$. The band at $710 \mathrm{~cm}^{-1}$ (spectrum c) broadens with the addition of PMMA/PVC (d) and then shifts to $714 \mathrm{~cm}^{-1}$ upon the addition of $\mathrm{LiN}\left(\mathrm{C}_{2} \mathrm{~F}_{5} \mathrm{SO}_{2}\right)_{2}$ (b). This shift may be due to the addition of lithium salt and these results are in accordance with the observations of our earlier results ${ }^{[14,15]}$ and other's observation ${ }^{[34]}$. Similarly, the peak at $724 \mathrm{~cm}^{-1}(\mathrm{e})$ is shifted to $728 \mathrm{~cm}^{-1}$ (f) upon the addition of lithium salt and is attributed due to the ring breathing phenomena of $\mathrm{EC}^{[35]}$. The spectral region of another ring deformation mode is given in Figure 8 (a-d). The band at $775 \mathrm{~cm}^{-1}$ is shifted towards $780 \mathrm{~cm}^{-1}$ fig (9b) in the polymer PVC/PMMA, plasticizer EC/PC and
$\mathrm{LiN}\left(\mathrm{C}_{2} \mathrm{~F}_{5} \mathrm{SO}_{2}\right)_{2}$ as salt. This may be attributed due to ionic association through re-distribution of charge accompanying the formation of ionic pairs and aggregation ${ }^{[14-15,33]}$.

The C-O stretching and $\mathrm{CH}_{2}$ rocking motions of $\mathrm{PC}$ are shown in Figure 9. The bands at $945 \mathrm{~cm}^{-1}$ and $955 \mathrm{~cm}^{-1}$ in pure PC (spectrum c) displays the same stretching behaviour in the polymer PVC+PMMA containing $\mathrm{LiN}\left(\mathrm{C}_{2} \mathrm{~F}_{5} \mathrm{SO}_{2}\right)_{2}$ salt. In the case of polymer blend containing PVC/PMMA the two bands narrow down at $965 \mathrm{~cm}^{-1}$ (b) whereas in the PVC:PMMA the two bands merged at $970 \mathrm{~cm}^{-1}($ Fig 9(a)). The bending mode of EC at $903 \mathrm{~cm}^{-1}$ (spectrum c) is shifted $970 \mathrm{~cm}^{-1}$ further, due to the addition of lithium salt and is attributed due to the strong interaction of $\mathrm{Li}^{+} \mathrm{EC}{ }^{[36]}$.

The $\mathrm{C}=\mathrm{O}$ stretching region of $\mathrm{PC}$ at $1800 \mathrm{~cm}^{-1}$ (Fig 10c) is considerably broadened when the polymer, PVC+PMMA, (d) is incorporated. A narrow peak is observed when the salt is incorporated [spectrum b]. These observations, that the broad peak becomes narrower after the addition of $\mathrm{Li}$ salt 

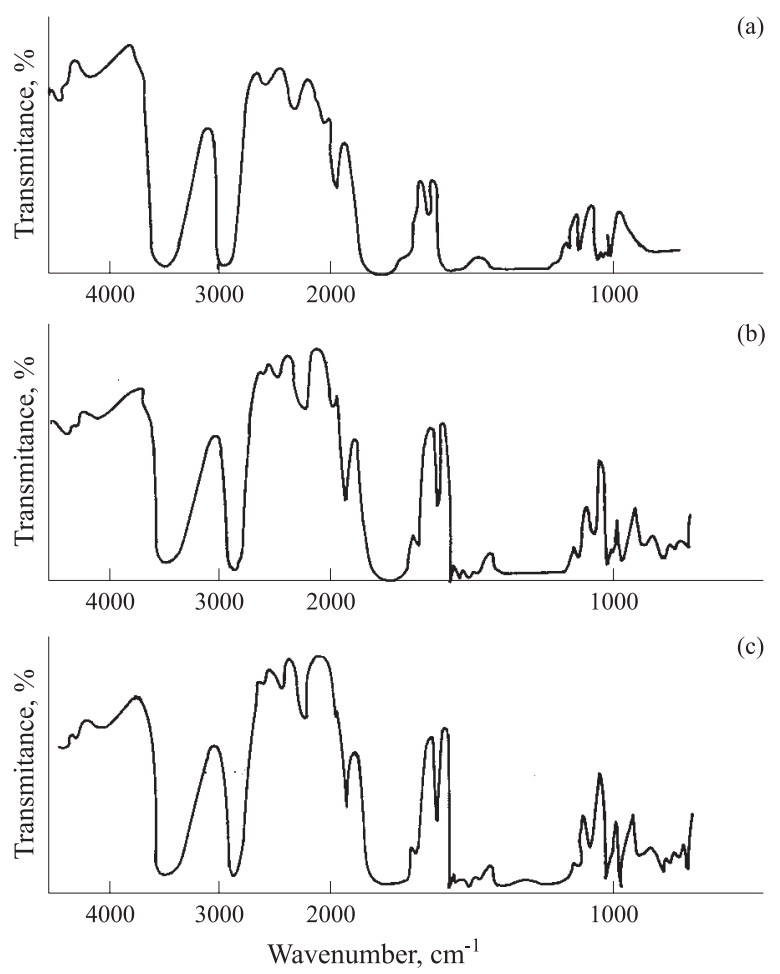

Figure 6. FTIR spectra of (a) PMMA (b) PVC (c) PVC+PMMA+ $\mathrm{EC}+\mathrm{PC}+\mathrm{LiN}\left(\mathrm{C}_{2} \mathrm{~F}_{5} \mathrm{SO}_{2}\right)_{2}$

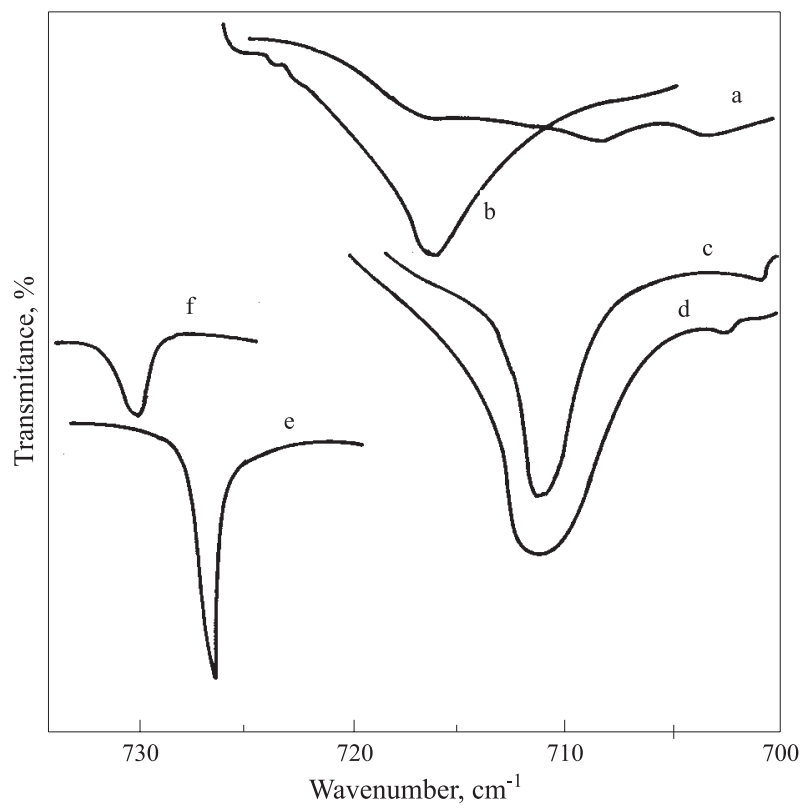

Figure 7. Symmetric ring deformation of $\mathrm{PC}$ (a) $\mathrm{PVC}+\mathrm{PMMA}$ (b) $\mathrm{PVC}+\mathrm{PMMA}+\mathrm{EC}+\mathrm{PC}+\mathrm{LiN}\left(\mathrm{C}_{2} \mathrm{~F}_{5} \mathrm{SO}_{2}\right)_{2}$ (c) $\mathrm{PC}$ (d) $\mathrm{PVC}+\mathrm{PMMA}+\mathrm{EC}+\mathrm{PC}$ (e) Ring breathing region of EC (f) $\mathrm{PVC}+\mathrm{PMMA}+\mathrm{EC}+\mathrm{PC}+\mathrm{LiN}\left(\mathrm{C}_{2} \mathrm{~F}_{5} \mathrm{SO}_{2}\right)_{2}$

and these results are consistent with that of earlier studies ${ }^{[14,15]}$ and with the data reported by Battisti et.al. ${ }^{[37]}$. A remarkable broadening of the PC bands when the polymer blend is added as seen in the figures earlier indicates a significant degree of interaction between the polymer host and the PC molecules. The decrease in the width of the band upon the addition of lithium salt is attributed due to the formation of

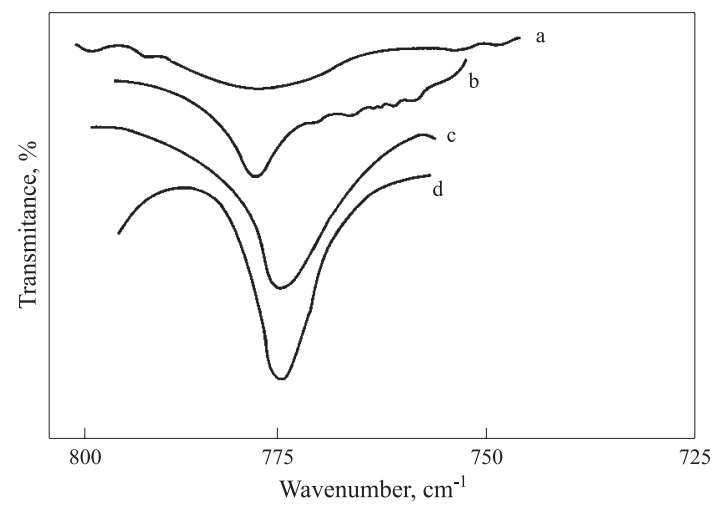

Figure 8. Spectral bands of another ring deformation of $\mathrm{PC}$ (a) PVC+PMMA (b) $\mathrm{PVC}+\mathrm{PMMA}+\mathrm{EC}+\mathrm{PC}+\mathrm{LiN}\left(\mathrm{C}_{2} \mathrm{~F}_{5} \mathrm{SO}_{2}\right)_{2}$ (c) $\mathrm{PC}$ (d) $\mathrm{PVC}+\mathrm{PMMA}+\mathrm{EC}+\mathrm{PC}$

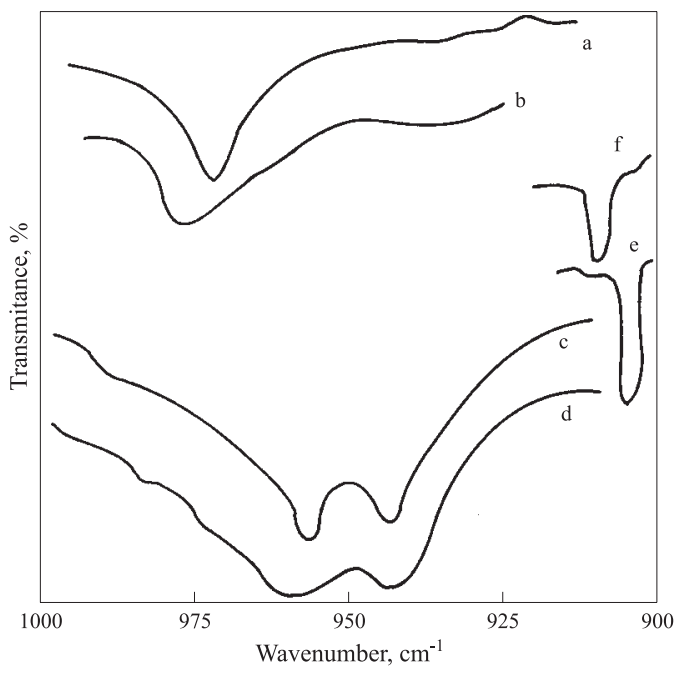

Figure 9. C-O Stretching and $\mathrm{CH}_{2}$ rocking region of $\mathrm{PC}$ (a) PVC+PMMA (b) $\mathrm{PVC}+\mathrm{PMMA}+\mathrm{EC}+\mathrm{PC}+\mathrm{LiN}\left(\mathrm{C}_{2} \mathrm{~F}_{5} \mathrm{SO}_{2}\right)_{2}$ (c) $\mathrm{PC}$ (d) $\mathrm{PVC}+\mathrm{PMMA}+\mathrm{EC}+\mathrm{PC}$ (e) ring bending region of $\mathrm{EC}(\mathrm{f})$ interaction of $\mathrm{EC}$ and $\mathrm{Li}^{+}$

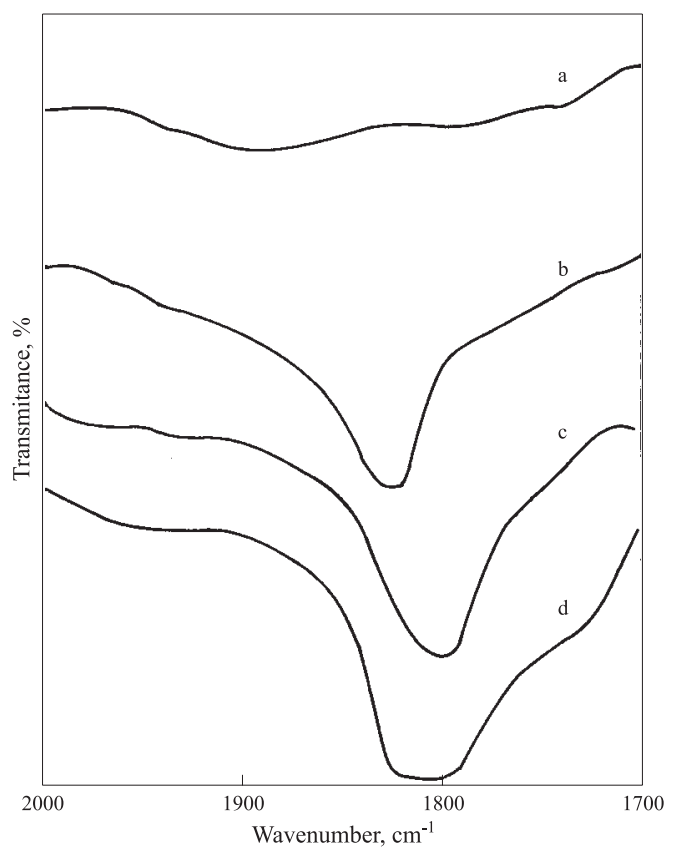

Figure 10. $\mathrm{C}=\mathrm{O}$ stretching region of $\mathrm{PC}$ (a) $\mathrm{PVC}+\mathrm{PMMA}$ (b) $\mathrm{PVC}+$ $\mathrm{PMMA}+\mathrm{EC}+\mathrm{PC}+\mathrm{LiN}\left(\mathrm{C}_{2} \mathrm{~F}_{5} \mathrm{SO}_{2}\right)_{2}$ (c) $\mathrm{PC}$ (d) $\mathrm{PVC}+\mathrm{PMMA}+\mathrm{EC}+\mathrm{PC}$ 
local structure or at least narrow distribution of intermolecular interactions ${ }^{[34]}$.

\section{Conclusion}

$\mathrm{LiN}\left(\mathrm{C}_{2} \mathrm{~F}_{5} \mathrm{SO}_{3}\right)_{2}$ based blend polymer films show appreciable conductivities above $40^{\circ} \mathrm{C}$. The ratio of 75:25 PMMA/PVC polymer blend at $60 \%$ plasticizer content is found to be suitable from the conductivity, electrochemical stability and thermal stability points of view. Although, impedance measurements and FT-IR studies cannot be correlated directly, the dissociation of ions greatly helps for ionic conduction and this type of spectroscopic studies can be used as a tool to identify the free anions, solvent shared ions, contact ion pairs and multiple ion aggregates. Studies of other electrochemical properties like, charge-discharge and cyclic voltammetry are in progress.

\section{Acknowledgement}

R.Nimma Elizabeth gratefully acknowledges Dr.Nirmala Jeyaraj, Principal, Lady Doak College for financial and facility support from Lady Doak College through UBCHEA program.

\section{References}

1. Fray F.M. - Solid polymer electrolytes-Fundamentals and Technological Applications, VCH, (1993).

2. Scrosati, B. - Applications of Electroactive polymers, London: Chapman and Hall, (1993)

3. Bertheir, C.; Gorecki, W.; Minier, M.; Armand, M. B.; Chanbagno, J. M. \& Rigaud,P. - Solid State Ionics 11, p.91 (1983).

4.. Abraham, K. M. \& Alamgir,M -J. Electrochem Soc ,137,p.1657 (1990).

5. Manuel Stephan, A.; Thirunakaran, R.; Renganathan, N.G.; Muniyandi, N.; Ramesh Babu,B.; In: Radhakrishna Editor, Trends in Materials Science, Vol 1. Allied Publishers, p99-105

6. Croce, F.; Brown, S.D.; Greenbaum, S.; Slane, S.M.\& Salamon,M.- Chem Mater.,5, p.1268 (1993).

7. Croce, F. \& Scrosati, B. - J Power Sources .,44,p.9 (1993).

8. Iijima, Y.; Tyoguchi, Y, \& Eda N.- Denki Kagaku, 53, p.619 (1985).

9. Appetecchi, G.B.; Croce, F. \& Scrosati, B. - Electrochim Acta ., 40, p.991 (1995).

10. Lee, L.H.; Park, J.K. \& Kim, H.D. - J Polym Sci B Polym Phys., 34, p.1427 (1996).

11. Lee, L.H.; Park, J.K. \& Kim, H.D. - J Polym Sci B Polym Phys., 37, p.247 (1996).

12. Abraham, K.M. \& Alamgir, A. - J Electrochem Soc., 140, p.L96 (1993).

13. Mary Sukeshini, A.; Nishimoto, A. \& Watanabe. M.- Solid State Ionics, 86-88,p.385 (1996).
14. Manuel Stephan, A.; Thirunakaran, R.; Renganathan, N.G.; Pitchumani, S.; Muniyandi, N. \& Rama moorthy, S.- J. Power Sources, 81-82,p.752 (1999).

15. Manuel Stephan, A.; Prem kumar, T.; Thirunakaran, R.;Renganathan, N.G.; Pitchumani, S. \& Muniyandi, N.- J. Power Sources, 89,p.80 (2000).

16. Manuel Stephan, A.; Prem kumar, T.; Thirunakaran, R.;Renganathan, N.G.; Pitchumani, S. \& Muniyandi, N.- Solid State Ionics ,130,p.123 (2000).

17. Kalyanasundaram, S.; Gopalan, A.;Yuria Saito,;Manuel Stephan,A.\& Nimma Elizabeth, R.- Ionics, 7,p.44 (2001).

18. Kalyanasundaram, S.; Gopalan, A.; Muniyandi, N.;Yuria Saito, Manuel Stephan, A,\& Nimma Elizabeth, R.Polym. Intl. (Communicated)

19. Rhoo,H.J.;Kim, H.T.;Park, J.M. \& Hwang, T.S.Electrochim Acta, 42, p.1571 (1997).

20. Capiglia,C; Saito,Y; Kataoka,H; Kodama,T; Quartarone, E; Mustarelli,P - Solid State Ionics 131,p.291 (2000).

21. Morita, M.; Tachihara, F.\& Matsuda, Y.- Electrochim. Acta, 32,p.299 (1987).

22. Prem Kumar, T.; Prabhu,V.S.S.; Kumar, B. \& Srinivasa,P.K.-J Power Sources, 50,p.283(1994).

23. Fauteax, D.- Solid State Ionics ,17,p.133 (1985).

24. Hiatani, M.; Miyauchi, K. \& Kudo, T.- Solid State Ionics 28-30,p.1431 (1988).

25. Peled, E.- J.Electrochem Soc., 126,p.2047 (1979).

26. Xu, W.; Soo, K.S,; Gao, Z. \& Lee, S.Y.- Electrochim Acta, 44,p.2287 (1999).

27. Wieczorek, W. \& Stevens, J.R.- J.Phys.Chem B., 101,p.1529 (1997).

28. Xu, W.; Siow, K.S.; Gao, Z. \& Lee, S.Y.- Solid State Ionics, 112,p.1 (1998).

29. Geronov, Y.; Schwager, F. \& Muller, R.H.- J.Electrochem Soc., 129,p.1422(1982)

30. Jiang, Z. \& Carrolb, B.- Electrochim Acta, 42,p.2667 (1997).

31. Shodai, T.; Owens, B.B.; Oh suke \& Yamakai J.- J Electrochem Soc.,141.p.2978 (1994).

32. Payne, D.R. \& Wright P.V.- Polymer, 23 ,p.690 (1982).

33. Appetecchi, G.B.; Careska, M.; Alessendrini, F.; Prosini, P.P.\& Passerni, S.- J Electrochem Soc., 147,p.451 (2000).

34. Starkey, S.R. \& Frech, R. Electrochim Acta, 42,p.471 (1997).

35. Wang, Z.; Huang, B.; Huang, H.; Xue, R.; Chen, L. \& Wang, F.- J.Electrochem Soc., 143,p.1510 (1996).

36.Weiwei, H.; Roger, F. \& Ralph A.W.- J.Phys.Chem., 98,p.100 (1994).

37. Battisti, D.; Nazri, G.A.; Klassen, B. \& Arora, R.J.Phys.Chem., 97,p.5826 (1993).

Recebido: 06/03/03

Aprovado:25/09/03 